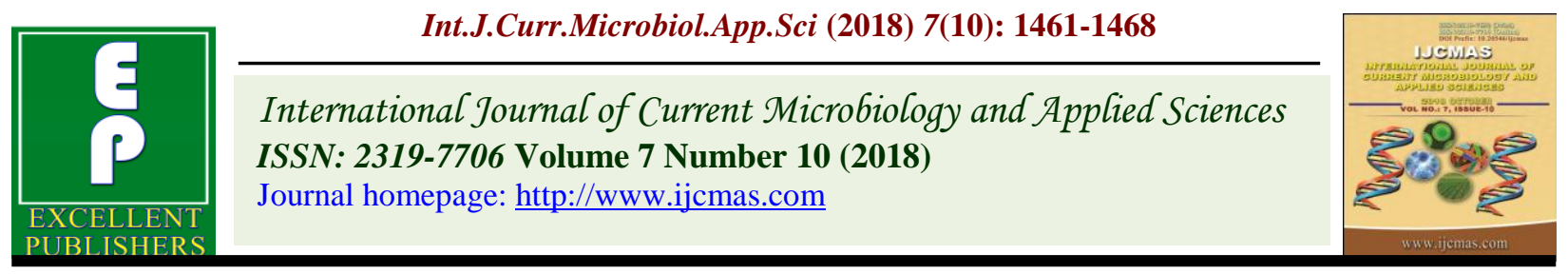

Original Research Article

https://doi.org/10.20546/ijcmas.2018.710.163

\title{
Response of Button Mushroom (Agaricus bisporus) and Oyster Mushroom (Pleurotus ostreatus) to Different Agricultural Waste and Soil
}

\author{
Amit Kumar Shukla and Arun A. David* \\ Department of Soil Science, Sam Higginbottom University of Agriculture, Technology and \\ Sciences, Allahabad 221 007, (U.P.), India \\ *Corresponding author
}

\section{A B S T R A C T}

\section{Keywords}

Oyster mushroom,

Button mushroom,

Soil, Paddy straw, Wheat straw

Article Info

Accepted:

12 September 2018

Available Online:

10 October 2018
An experiment was conducted during rabi season 2016-17 in dark room on crop research farm of department of Soil Science and Agricultural Chemistry, Naini Agricultural Institute, SHUATS Allahabad. The experiment was laid out in Randomized Block Design with an objective of to study the growth, yield and nutrition content of mushroom with physical and chemical properties of soil which was used as growing of mushroom. There was 14 treatments combination replicated thrice. The different treatments were allocated randomly in each replication. Both the Mushroom varieties grown in $100 \%$ straw gave the significant maximum height, weight and width. Combination of $25 \%$ Soil $+75 \%$ Paddy Straw + Oyster Mushroom recorded significant maximum height, weight and width of mushroom. Treatment $\mathrm{T}_{12}$ (@ 25\% Soil Science Soil + @ 75\% Paddy Straw + Oyster Mushroom) was found to be at par with $\mathrm{T}_{2}$ (Paddy Straw @ 100\% + Oyster Mushroom) in height, weight and width of mushroom. All the soil parameters viz., Bulk density $\left(\mathrm{g} \mathrm{cm}^{-3}\right)$, Particle density $\left(\mathrm{g} \mathrm{cm}^{-3}\right)$, Pore space (\%), Water holding capacity (\%), Organic carbon (\%), Available Nitrogen $\left(\mathrm{kg} \mathrm{ha}^{-1}\right)$, Available Phosphorus $\left(\mathrm{kg} \mathrm{ha}^{-1}\right)$ and Available Potassium $(\mathrm{kg}$ $\mathrm{ha}^{-1}$ ) was also recorded maximum in treatment $\mathrm{T}_{12}$.

\section{Introduction}

Mushroom with their great variety of species, constitute a cost-effective means of both supplementing the nutrition to human kinds. 4-5 species of mushroom are of industrial significance throughout the world (Chang and Miles, 1992). Oyster mushroom (Pleurotus sp.) belonging to Class Basidiomycetes and Family Agaricaceae is popularly known as 'Dhingri' in India and grows naturally in the temperate and tropical forests on dead and decaying wooden logs or sometimes on dying trunks of deciduous or coniferous woods. It may also grow on decaying organic matter. Produces protein rich food Oyster mushrooms are the third largest cultivated mushroom. The economic importance of the mushroom lies primarily in its use as food for human consumption. It is rich in Vitamin C and B complex and the protein content varies between 1.6 to 2.5 percent and mineral salts required for the human body. The accumulation of trace metals in agricultural soils disposal, waste incineration, urban effluent, traffic is of increasing concern due to 
the food safety issues and potential health risks as well as its detrimental effects on soil ecosystems. Heavy metals are considered to be one of the main sources of pollution in the environment, since they have a significant effect on its ecological quality. Human activity leads to increasing levels of heavy metal contamination in the environment. Heavy metals owing to atmospheric and industrial pollution accumulate in the soil and influence the ecosystem nearby. The determination of heavy metal in soils is very important in monitoring environmental pollution. Lead has no beneficial role in human metabolism, producing progressive toxicity (Chauhan, 2014). Hence, the present investigation is carried out to the study the Response of button mushroom (Agaricus bisporus) and oyster mushroom (Pleurotus ostreatus) to different agricultural waste and soil.

\section{Materials and Methods}

The experiment was conducted in the Dark Room, situated in Crop Research Farm, Department of Soil Science and Agricultural Chemistry, Sam Higginbottam University of Agriculture, Technology and Sciences Allahabad. The treatments were $\mathrm{T}_{1}=$ Wheat Straw@100\% + Button Mushroom; $\mathrm{T}_{2}=$ Paddy Straw@100\% + Oyster Mushroom; $\mathrm{T}_{3}=@ 50 \%$ Agronomy Soil + @ 50\% Wheat Straw + Button Mushroom; $\mathrm{T}_{4}=@ 50 \%$ Agronomy Soil + @ 50\% Paddy Straw + Oyster Mushroom; $\mathrm{T}_{5}=@ 50 \%$ Soil Science Soil + @ 50\% Wheat Straw + Button Mushroom; $\mathrm{T}_{6}=@$ @ 50\% Soil Science Soil + @ 50\% Paddy Straw + Oyster Mushroom; $\mathrm{T}_{7}=@$ $50 \%$ Plant Breeding Soil + @ 50\% Wheat Straw + Button Mushroom; $\mathrm{T}_{8}=@ 50 \%$ Plant Breeding Soil + @ 50\% Paddy Straw + Oyster Mushroom; $\mathrm{T}_{9}=$ @ 25\% Agronomy Soil + @ 75\% Wheat Straw + Button Mushroom; $\mathrm{T}_{10}=$ @ 25\% Agronomy Soil + @ 75\% Paddy Straw + Oyster Mushroom; $\mathrm{T}_{11}=$ @ 25\% Soil
Science Soil + @ 75\% Wheat Straw + Button Mushroom; $\mathrm{T}_{12}=$ @ 25\% Soil Science Soil + @ 75\% Paddy Straw + Oyster Mushroom; $\mathrm{T}_{13}=@ 25 \%$ Plant Breeding Soil + @ 75\% Wheat Straw + Button Mushroom; $\mathrm{T}_{14}=@$ 25\% Plant Breeding Soil + @ 75\% Paddy Straw + Oyster Mushroom. Mother spawn was prepared from the pure culture obtained from Mushroom Research Laboratory of the Department of Plant Pathology, CSAUAT, Kanpur. Wheat grains were used as substrates for the preparation of mother spawn. Spawn required for different studies was multiplied from mother spawn using both glucose bottles and double polythene bags. In the glucose bottles/bags, $250 \mathrm{~g}$ of wheat grains were taken and inoculated with a spoonful of grains from mother spawn. The glucose bottles bags were then incubated same as mother spawn. Paddy straw and wheat straw were chopped into pieces of 4-5 cm with the help of chaff cutter. The straw substrates were dipped in water (already mixed with 75 ppm bavistin and 500 ppm formaldehyde) for 14 hours as per the method described by Vijay and Sohi (1987). Excess water was drained off by spreading the straw on the sloppy cemented floor till the moisture content of straw reached to $65-70 \%$. Before spawning, formaldehyde was sprinkled on the floor, the spawn was then mixed to the substrate by layering method @ 3\% by wet weight basis. Mixing of spawn with the substrate was done in an open room. The spawned substrate was filled in the polythene bags (12"x18"-150 gauge) and nylon strings was employed for tieing the mouth of the bags. Perforations were made with the help of nail to allow free passage of air within the polythene bags. The filled bags were kept in the cropping room made of dark room roofing. High humidity in the cropping room was maintained by frequent watering of the bags and of the floor. Polythene covers were removed after the completion of spawn run. Period of spawn run (days) was observed when the straw was fully covered with milky 
white mycelial growth of the fungus (Agaricus bisporus, Pleurotus ostreatus). The mushroom was spawning on $9^{\text {th }}$ December 2016. The mushroom beds were hanged by nylon strings at a distance of $30-40 \mathrm{~cm}$ apart. These beds were watered thrice a day. Watering was stopped a day before harvesting and again continued. Diffused light and good ventilation was provided during the entire cropping period. Standard procedure was followed to collect the data for growth and yield parameters. The collected data were analyzed statistically by using Fisher's analysis of variance technique and $\mathrm{CD}$ at $5 \%$ probability was used to compare the differences among treatments means (Steel et al., 1997).

\section{Results and Discussion}

\section{Growth and yield of mushroom}

Significantly higher mushroom height, weight and width were recorded under treatment $\mathrm{T}_{2}$ $100 \%$ Paddy straw @ bag + Oyster Mushroom (Total volume of bag $5 \mathrm{~kg}$ ). However, mushroom height recorded under the treatments $\mathrm{T}_{12}-25 \%$ Soil science sandy loam soil@bag+75\% Paddy straw @ bag + Oyster Mushroom (Total volume of bag $5 \mathrm{~kg}$ ) was found to be statistically at par with $\mathrm{T}_{2}$. Mushroom weight recorded under the treatments $\mathrm{T}_{6} \quad 50 \%$ Soil science and Agricultural chemistry sandy loam soil @ bag $+50 \%$ Paddy straw + Oyster Mushroom (Total volume of bag $5 \mathrm{~kg}$ ), $\mathrm{T}_{14} 25 \%$ Genetics and plant breeding sandy loam soil @ bag + 75\% Paddy straw @ bag + Oyster Mushroom (Total volume of bag $5 \mathrm{~kg}$ ) and $\mathrm{T}_{1} 100 \%$ Wheat straw @ bag + Button Mushroom (Total volume of bag $5 \mathrm{~kg}$ ), $\mathrm{T}_{4} 25 \% 50 \%$ Agronomy sandy loam soil @ bag + 50\% Paddy straw@bag + Oyster Mushroom (Total volume of bag $5 \mathrm{~kg}$ ) respectively was found to be statistically at par with $\mathrm{T}_{2}$. plant width recorded under the treatments $\mathrm{T}_{1} 100 \%$ Wheat straw @ bag + Button Mushroom
(Total volume of bag $5 \mathrm{~kg}$ ), $\mathrm{T}_{12} 25 \%$ Soil science and Agricultural chemistry sandy loam soil@ bag + 75\% Paddy straw @ bag + Oyster Mushroom (Total volume of bag $5 \mathrm{~kg}$ ), $\mathrm{T}_{14} 25 \%$ Genetics and plant breeding sandy loam soil @ bag + 75\% Paddy straw @ bag + Oyster Mushroom (Total volume of bag $5 \mathrm{~kg}$ ) respectively at variation in plant 45 DAS, were found to be statistically at par with $T_{2}$. The maximum height, weight and width were recorded by Oyster mushroom. This might be due to their inherent characteristic. Similar finding was also reported by Rosado et al., (2002). All the rice straw treatment recorded the highest width of mushroom. Suitability of paddy straw in Oyster mushroom cultivation has been reported by Ram, (2010); and Arya and Arya, (2003). Lower amount of sandy loam soil gave the good performance in width of mushroom. This might be due to the soil particles break the growth of mycelium of mushroom and can be used as casing layer. Similar results was reported by Sassine et al., (2007); Manjulal et al., (2004).

Appraisal of the mean data showed significant variation on yield of mushroom. Significantly higher mushroom yield was recorded for treatment $\mathrm{T}_{2} 100 \%$ Paddy straw @ bag + Oyster Mushroom (Total volume of bag $5 \mathrm{~kg}$ ) (2.89). However, mushroom yield recorded under the treatments $\mathrm{T}_{1} 100 \%$ Wheat straw @ bag + Button Mushroom (Total volume of bag $5 \mathrm{~kg}), \mathrm{T}_{10} 25 \%$ Agronomy sandy loam soil @ bag + 75\% Paddy straw @ bag + Oyster Mushroom (Total volume of bag $5 \mathrm{~kg}$ ), $\mathrm{T}_{14}$ 25\% Genetics and plant breeding sandy loam soil @ bag + 75\% Paddy straw @ bag + Oyster Mushroom (Total volume of bag $5 \mathrm{~kg}$ ) was found to be at par with $\mathrm{T}_{2} 100 \%$ Paddy straw@bag+Oyster Mushroom.

Yield is a complex character resulting from the interaction from primary inherited character of the mushroom and with the environment and management (Table 1 and 2). 
Table.1 Effect of different agricultural cereal crop straw and sandy loam soil on width $(\mathrm{cm})$ of button and oyster mushroom

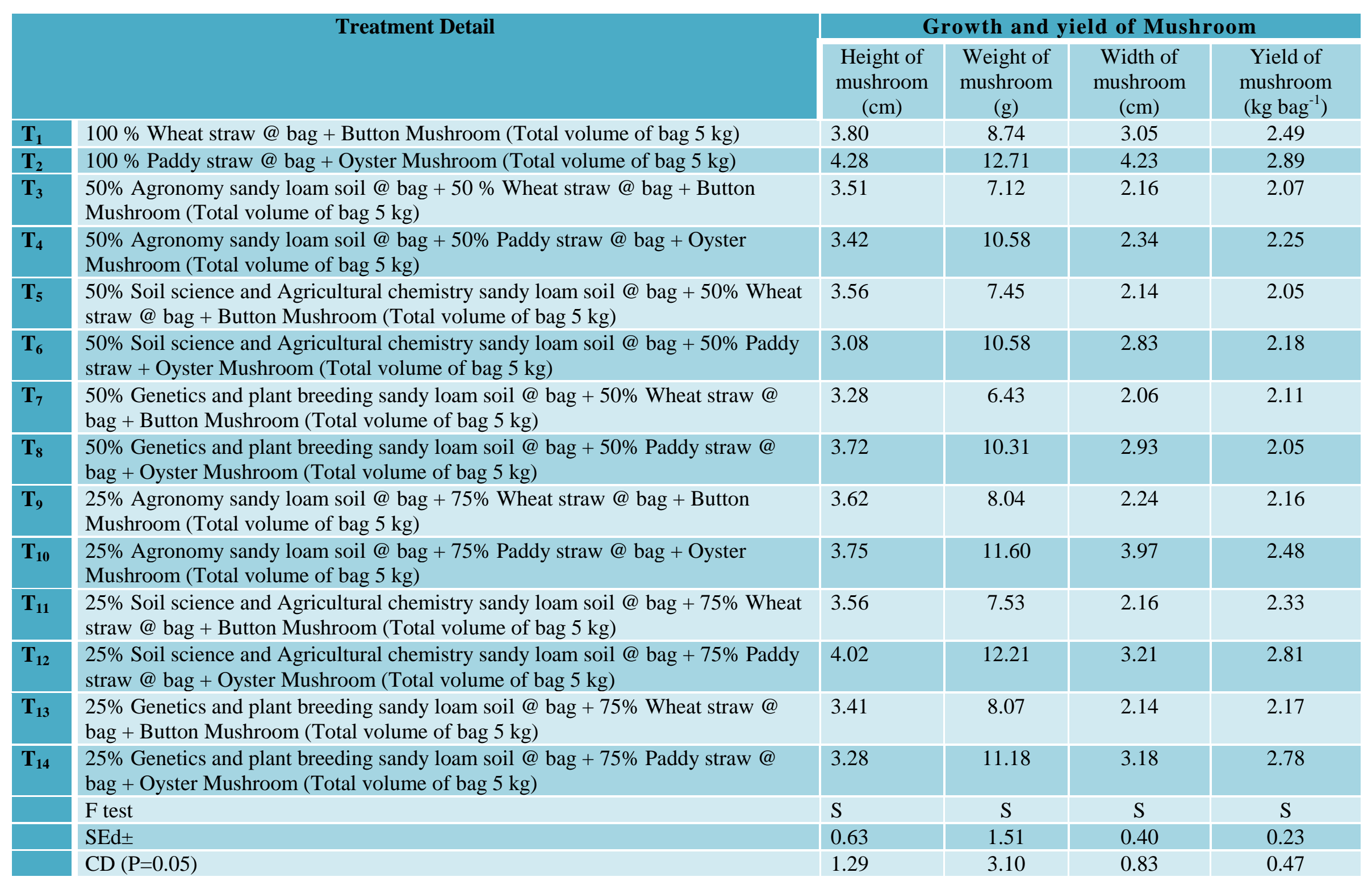


Table.2 Effect of button and oyster mushroom, different agricultural cereal crop straw and sandy loam soil on nitrogen phosphorus and potassium content in mushroom at harvest

\begin{tabular}{|c|c|c|c|c|}
\hline & Treatment Detail & $\begin{array}{l}\text { Nitrogen content } \\
(\%)\end{array}$ & $\begin{array}{l}\text { Phosphorus } \\
\text { content }(\%)\end{array}$ & $\begin{array}{l}\text { Potassium } \\
\text { content }(\%)\end{array}$ \\
\hline $\mathbf{T}_{1}$ & $100 \%$ Wheat straw @ bag + Button Mushroom (Total volume of bag 5 kg) & 1.13 & 0.21 & 0.12 \\
\hline $\mathbf{T}_{2}$ & $100 \%$ Paddy straw @ bag + Oyster Mushroom (Total volume of bag 5 kg) & 1.66 & 0.27 & 0.17 \\
\hline $\mathbf{T}_{3}$ & $\begin{array}{l}50 \% \text { Agronomy sandy loam soil @ bag + 50\% Wheat straw@ @ag + Button } \\
\text { Mushroom (Total volume of bag } 5 \mathrm{~kg} \text { ) }\end{array}$ & 1.27 & 0.31 & 0.19 \\
\hline $\mathbf{T}_{4}$ & $\begin{array}{l}50 \% \text { Agronomy sandy loam soil @ bag + 50\% Paddy straw @ bag + Oyster } \\
\text { Mushroom (Total volume of bag } 5 \mathrm{~kg} \text { ) }\end{array}$ & 1.26 & 0.28 & 0.18 \\
\hline $\mathbf{T}_{5}$ & $\begin{array}{l}50 \% \text { Soil science and Agricultural chemistry sandy loam soil @ bag }+50 \% \text { Wheat } \\
\text { straw + Button Mushroom (Total volume of bag } 5 \mathrm{~kg} \text { ) }\end{array}$ & 1.25 & 0.28 & 0.18 \\
\hline $\mathbf{T}_{6}$ & $\begin{array}{l}\text { 50\% Soil science and Agricultural chemistry sandy loam soil @ bag + 50\% Paddy } \\
\text { straw + Oyster Mushroom (Total volume of bag } 5 \mathrm{~kg} \text { ) }\end{array}$ & 1.24 & 0.26 & 0.16 \\
\hline $\mathrm{T}_{7}$ & $\begin{array}{l}50 \% \text { Genetics and plant breeding sandy loam soil @ bag +50\% Wheat straw @ bag } \\
\text { + Button Mushroom (Total volume of bag } 5 \mathrm{~kg} \text { ) }\end{array}$ & 1.21 & 0.27 & 0.17 \\
\hline $\mathrm{T}_{8}$ & $\begin{array}{l}50 \% \text { Genetics and plant breeding sandy loam soil @ bag + 50\% Paddy straw @ bag } \\
+ \text { Oyster Mushroom (Total volume of bag } 5 \mathrm{~kg} \text { ) }\end{array}$ & 1.20 & 0.24 & 0.14 \\
\hline $\mathrm{T}_{9}$ & $\begin{array}{l}\text { 25\% Agronomy sandy loam soil @ bag + 75\% Wheat straw @ bag + Button } \\
\text { Mushroom (Total volume of bag } 5 \mathrm{~kg} \text { ) }\end{array}$ & 1.21 & 0.26 & 0.16 \\
\hline$T_{10}$ & $\begin{array}{l}\text { 25\% Agronomy sandy loam soil @ bag + 75\% Paddy straw @ bag + Oyster } \\
\text { Mushroom (Total volume of bag } 5 \mathrm{~kg} \text { ) }\end{array}$ & 1.20 & 0.24 & 0.14 \\
\hline $\mathbf{T}_{11}$ & $\begin{array}{l}25 \% \text { Soil science and Agricultural chemistry sandy loam soil @ bag }+75 \% \text { Wheat } \\
\text { straw @ bag + Button Mushroom (Total volume of bag } 5 \mathrm{~kg} \text { ) }\end{array}$ & 1.21 & 0.26 & 0.16 \\
\hline$T_{12}$ & $\begin{array}{l}\text { 25\% Soil science and Agricultural chemistry sandy loam soil @ bag + 75\% Paddy } \\
\text { straw @ bag + Oyster Mushroom (Total volume of bag } 5 \mathrm{~kg} \text { ) }\end{array}$ & 1.20 & 0.20 & 0.10 \\
\hline $\mathbf{T}_{13}$ & $\begin{array}{l}\text { 25\% Genetics and plant breeding sandy loam soil @ bag + 75\% Wheat straw @ bag } \\
+ \text { Button Mushroom (Total volume of bag } 5 \mathrm{~kg} \text { ) }\end{array}$ & 1.11 & 0.20 & 0.11 \\
\hline $\mathbf{T}_{14}$ & $\begin{array}{l}\text { 25\% Genetics and plant breeding sandy loam soil @ bag + 75\% Paddy straw @ bag } \\
\text { + Oyster Mushroom (Total volume of bag } 5 \mathrm{~kg} \text { ) }\end{array}$ & 1.57 & 0.26 & 0.14 \\
\hline & F test & S & $\mathrm{S}$ & $\mathrm{S}$ \\
\hline & $\mathrm{SEd} \pm$ & 0.13 & 0.01 & 0.01 \\
\hline & $\mathrm{CD}(\mathrm{P}=0.05)$ & 0.27 & 0.02 & 0.02 \\
\hline
\end{tabular}




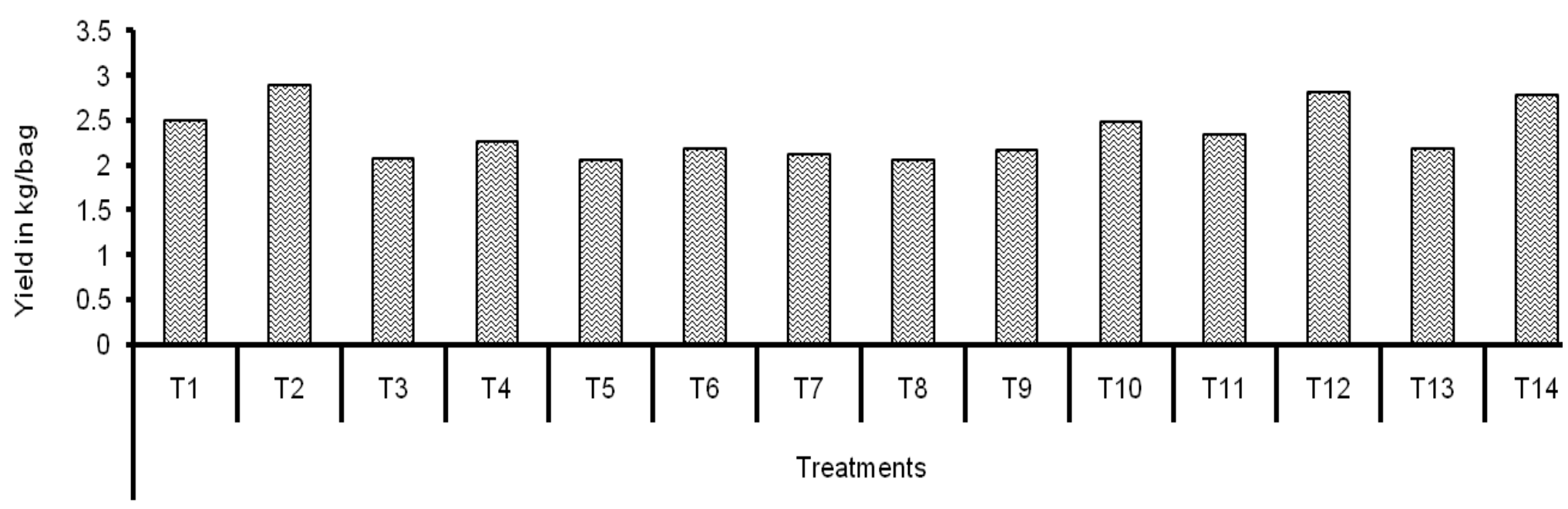

Fig.- 1: . Effect of different Agricultural cereal crop Straw and Sandy loam soil on Yield of Button and Oyster mushroom 
For top fruiting bodies yield, the trio-complex of ecological situation, the genetic potential and the management practices are of utmost importance. If the previous two requirements are commonly shared, the fate of the crop will naturally by determined by management practice. The maximum yield was recorded by Oyster mushroom. This might be due to their inherent characteristic. Oyster mushroom can grow at moderate temperatures, ranging from 20 to $30^{\circ} \mathrm{C}$, and at a humidity of $55-70 \%$, on various agricultural waste materials used as substrate.

Similar finding was also reported by Rosado et al., (2002). All the rice straw treatment recorded the highest yield of mushroom. Suitability of paddy straw in Oyster mushroom cultivation has been reported by Ram, (2010); and Arya and Arya, (2003). Lower amount of sandy loam soil gave the good performance in yield of mushroom.

This might be due to the soil particles break the growth of mycelium of mushroom and can be used as casing layer. Similar result was reported by Sassine et al., (2007).

\section{NPK content in mushroom}

Significantly higher nitrogen content in mushroom was recorded under treatment $\mathrm{T}_{2}$ $100 \%$ Paddy straw @ bag + Oyster Mushroom (Total volume of bag $5 \mathrm{~kg}$ ) (1.66). However, treatments $\mathrm{T}_{14} 25 \%$ Genetics and plant breeding sandy loam soil @ bag $+75 \%$ Paddy straw @ bag + Oyster Mushroom (Total volume of bag $5 \mathrm{~kg}$ ), $\mathrm{T}_{3} \quad 50 \%$ Agronomy sandy loam soil @ bag + 50\% Wheat straw @ bag + Button Mushroom (Total volume of bag $5 \mathrm{~kg}$ ), $\mathrm{T}_{4} \quad 50 \%$ Agronomy sandy loam soil @ bag + 50\% Paddy straw @ bag + Oyster Mushroom (Total volume of bag $5 \mathrm{~kg}$ ) were found to be at par with $\mathrm{T}_{2} 100 \%$ Paddy straw @ bag + Oyster Mushroom.
A close scrutiny of mean data showed higher phosphorus and potassium content in mushroom under treatment $\mathrm{T}_{3} \quad 50 \%$ Agronomy sandy loam soil @ bag + 50\% Wheat straw @ bag + Button Mushroom (Total volume of bag $5 \mathrm{~kg}$ ) (0.31 and 0.19$)$. However, treatments $\mathrm{T}_{4} 50 \%$ Agronomy sandy loam soil @ bag + 50\% Paddy straw @ bag + Oyster Mushroom (Total volume of bag $5 \mathrm{~kg}), \mathrm{T}_{7} 50 \%$ Genetics and plant breeding sandy loam soil @ bag + 50\% Wheat straw @ bag + Button Mushroom (Total volume of bag $5 \mathrm{~kg}), \mathrm{T}_{11} 25 \%$ Soil science and Agricultural chemistry sandy loam soil @ bag + 75\% Wheat straw@bag + Button Mushroom (Total volume of bag $5 \mathrm{~kg}$ ) were found to be at par with $\mathrm{T}_{3}$ in case of phosphorus and treatments $\mathrm{T}_{4} 50 \%$ Agronomy sandy loam soil @ bag + 50\% Paddy straw @ bag + Oyster Mushroom (Total volume of bag $5 \mathrm{~kg}$ ), $\mathrm{T}_{7}$ $50 \%$ Genetics and plant breeding sandy loam soil @ bag + 50\% Wheat straw @ bag + Button Mushroom (Total volume of bag 5 $\mathrm{kg}), \mathrm{T}_{11} 25 \%$ Soil science and Agricultural chemistry sandy loam soil @ bag + 75\% Wheat straw@bag + Button Mushroom (Total volume of bag $5 \mathrm{~kg}$ ) were found to be at par with $\mathrm{T}_{3} 50 \%$ Agronomy sandy loam soil @ bag + 50\% Wheat straw @ bag + Button Mushroom in case of potassium.

The higher nitrogen content in mushroom was recorded under the treatment of $T_{2}$ might be due to the rice straw is to provide a reservoir of cellulose, hemicelluloses, lignin and nitrogen which is highly utilized by oyster mushroom. Similar result was reported by Yildiz et al., (2002). Similarly, maximum phosphorus and potassium content were recorded under $\mathrm{T}_{3}$ might be due to the maximum phosphorus and potassium content in soil and wheat straw.

It may be concluded that treatment $\mathrm{T}_{2} 100 \%$ Paddy straw@bag + Oyster Mushroom gave the maximum height, weight, width and yield 
of mushroom. Treatment $\mathrm{T}_{2} 100 \%$ Paddy straw@bag + Oyster Mushroom gave the higher yield. However, all the combinations of $25 \%$ soil $+75 \%$ paddy straw gave the better response with Oyster mushroom. So, it is recommended for the marginal farmers as well as small and big farmers. The compost obtained after the harvesting of mushroom is good manure and can be utilize for crop production.

\section{Acknowledgment}

The author are thankful to the Hon'ble Vicechancellor, SHUATS and Head, Department of Soil Science and Agricultural Chemistry, Naini Agricultural Institute, Sam Higgin Bottom University of Agriculture, Technology and Sciences, Allahabad - 211 007, (U.P.), India for providing the facilities during the course of investigation.

\section{References}

Arya, C., Arya, A. (2003). Effect of acid hydrolysis of substrate on the yield of oyster mushroom (P.sajor- caju $(F r$.) Singer) Mush. Res. 12 (1): 35-38.

Chang S.T. and Miles P.G. (1992). Mushroom biology - A new discipline. Mycologist, 6: 64-65.

Chauhan Monika (2014). Bioaccumulation of lead content in Mushroom and Soil in Delhi-NCR Region of India. IJARCS. 1: 1-6.
Manjual, R.L., Seth, P.K. and Shandilya, T.R. (2004). Pathogens and competitors of Agaricus bisporus and their control. Indian J. Mushroom. 3: 31-40

Ram, R.C. and Kumar, S. (2010). Agricultural wastes used as casing mixtures for production of button mushroom. Indian J.Sci Res. 1 (1):21-25.

Rosado, F.R., Carbonero, E.R., Kemmelmeier, C., Tischer, C.A.; Gorin, P.A.J. and Iacomini, M. (2002). A partially 3 methylated linked add galactan and mannan from Pleurotus ostreatoroseus Sing. FEMS Microbiology Letter, 212: 261265, DOI: 10.1111/j.15746968.2002. tb11276.x.

Sassine, Y.N., Abdel, A.M.R. and Ghora, Y. (2007). Effect of different mixtures with waste paper as casing soil on the growth and production of mushroom (Agaricus bisporus). Australian journal of basic and Applied Sciences, 1 (2): 96-104.

Steel, R.G.D., J.H. Torrie and D.A. Dickey, (1997). Principals and procedures of statistics. Abiometric approach $3^{\text {rd }} \mathrm{Ed}$. McGraw Hill Book Co.Inc. N.Y.

Vijay, B. and Sohi, H.S. (1987). Effect of different sterilants and farm wastes on yield of pleurotus citrinopileatus. Mush J Tropics. 7: 67-75.

Yildiz, S., Yildiz, U.C., Gezer, E.D. and Temiz, A. (2002). Some lignocellulosic wastes used as raw material in cultivation of the Pleurotus ostreatus culture mushroom. Pro Biochem 38: 301-306.

\section{How to cite this article:}

Amit Kumar Shukla and Arun A. David. 2018. Response of Button Mushroom (Agaricus bisporus) and Oyster Mushroom (Pleurotus ostreatus) to Different Agricultural Waste and Soil. Int.J.Curr.Microbiol.App.Sci. 7(10): 1461-1468.

doi: https://doi.org/10.20546/ijcmas.2018.710.163 